Journal of Anatolian Environmental and Animal Sciences (Anadolu Çevre ve Hayvanculı Bilimleri Dergisi)

DOI: https://doi.org/10.35229/jaes.724188

\title{
Artvin Ladin Ormanlarında Ips typographus L. (Coleoptera: Curculionidae: Scolytinae)'un Epidemi Yapmasına Toprak Yapısının Etkileri
}

\author{
Mimar Sinan ÖZKAYA \\ Artvin Orman Bölge Müdürlüğ̈̈, Artvin, Türkiye
}

Atıf yapmak için: Özkaya, M.S. (2020). Artvin Ladin Ormanlarında Ips typographus L. (Coleoptera: Curculionidae: Scolytinae)'un Epidemi Yapmasına Toprak Yapısının Etkileri. Anadolu Cev. ve Hay. Dergisi, 5(2), 245-252.

How to cite: Özkaya, M.S. (2020). Some Soil properties in healthy and unhealthy stands dominated with Oriental Spruce in Artvin under threat of Ips typographus L.. J. Anatolian Env. and Anim. Sciences, 5(2), 245-252.

iD : https://orcid.org/0000-0003-2146-3867

*Sorumlu yazarın:

Mimar Sinan ÖZKAYA

Artvin Orman Bölge Müdürlüğü, Artvin,

Türkiye.

凶: mimarsinanozkaya@ogm.gov.tr

Cep telefonu : +90 (505) 3788000
Öz: Artvin Orman Bölge Müdürlüğü Ladin (Picea orientalis) ormanlarında ilk kez 1984 yılında tespit edilen Ips typographus (Sekiz Dişli Kabuk Böceği) ile mekanik, biyoteknik ve biyolojik mücadele yapılarak doğal denge sağlanmıştı. Ancak 2013 yılından itibaren böcek yoğunluğunda ve kurumalarda artışlar görülmüştür. Bu kurumaların iklim ve toprak kaynaklı olduğu düşünülmüştür. Bu amaçla son yıllarda yaşanan kuraklık ile topraktaki değişimlerin araştırılması için ağaç kurumalarının yoğun olduğu ormanlık alanlarda ve bitişiğindeki sağlıklı alanlarda toprak özellikleri incelenmiştir. Ladin ağaçlarının kuruma gösterdiği ve sağlıklı yetiştiği sahalardan alınan toprak örneklerinin tahlilinde, sağlıklı sahadaki organik madde miktarının ortalama $\% 5,48, \mathrm{pH}$ değeri 6,09 , kum oranı değeri \% 64,44 , kil oranı değeri \%22,08 ve toz oranı değeri \%13,48 bulunmuştur. Kurumaların yoğun olduğu sahalardan alınan topraklarda organik madde miktarının \%5,58, $\mathrm{pH}$ değerinin 6,01 , kum oranının $\% 51,52$, kil oranının \%28,94 ve toz oranının \%19,54 olduğu tespit edilmiştir. Kurumaların yoğun olduğu sahalardaki topraklarda kil miktarının, sağlıklı ladin bireylerinin bulunduğu sahalara oranla daha fazla olması, toprakta kötü havalanma koşullarını oluşturmuş ve köklerin derin toprak katmanlarına ulaşmasını engellemiş olma olasılığına dayandırılabilir. Bu durum, derin toprak katmanlarından su alamayan ladin ağaçlarının da daha fazla strese girmesi nedeniyle zayıf düşmesi ve böylece böcek zararına maruz kaldıkları şeklinde yorumlanmıştır.

\section{Some Soil properties in healthy and unhealthy stands dominated with Oriental Spruce in Artvin under threat of Ips typographus $\mathrm{L}$.}

\author{
"Corresponding author's: \\ Mimar Sinan ÖZKAYA \\ Artvin Regional Directorate of Forestry, \\ Artvin, Turkey. \\ 凶: mimarsinanozkaya@ogm.gov.tr \\ Mobile telephone : +90 (505) 3788000
}

\begin{abstract}
Ips typographus (Eight Toothed Bark Beetle) was first observed in stands dominated with Picea orientalis (oriental spruce) under management of Artvin Regional Forest Directorate. Since then mechanical, biotechnical and biological control techniques were exercised in combating the pest for the stands' health and vitality. However, the population of the insect has increased since 2013. This might be attributed to the soil condition and climate change considering mainly drought and soil properties in changing environment encountered in the region recently. Soil properties were analyzed in soil samples taken from the healthy stands and the adjacent stands where the oriental spruce tree mortality occurred. The average percentage of organic matter, sand clay, silt and value of $\mathrm{pH}$ were found as $5.48 \%, 64.44 \%, 22.08 \%, 13.48 \%$ and 6.09 in healthy stands, respectively. It has been determined in soils where tree dieback is intense that the amount of organic matter is $5.58 \%$, the $\mathrm{pH}$ value is 6.01 , the sand rate is $51.52 \%$, the clay rate is $28.94 \%$ and the silt rate is $19.54 \%$. The amount of clay in the soils of areas with dense dieback than the healthy spruce areas soils can be based on the possibility of bad ventilation conditions in the soil and preventing the roots to reach deep soil layers. This situation has been interpreted as spruce trees, which cannot get water from the deep soil layers, fall weak due to more stress and thus they are exposed to insect damage.
\end{abstract}

Keywords: Ips typographus, Picea orientalis, soil properties, stand. 


\section{GíRiş}

Ormanlar sahip oldukları kaynak değerleri bakımından; ülkelerin korunmasında, kalkınmasında ve sürdürülebilir yaşam kalitesinin sağlanmasında çok güçlü bir kaynak değerine sahiptir (Yüksek, 2017). Artvin Orman Bölge Müdürlüğü ormanları, zararlı organizmalar için Türkiye ile Gürcistan arasında geçiş noktası olarak kabul edilebilir. Doğu Karadeniz ladin ormanları 1970'li yıllardan itibaren Dendroctonus micans (Kugelann)'ın, 1984'lı y1llardan itibaren ise Ips typographus (L.)'un yoğun olarak zararına uğrayarak zayıf düşmüştür (Keskinalemdar vd., 1987; Göktürk, 2009; Coşkun vd., 2010; Göktürk vd., 2011). D.micans ile 1985-2003 y1lları arasında laboratuvar şartlarında Rhizophagus grandis üretilip, böceğin zarar yaptığı ağaçlara verilerek biyolojik mücadele yapılmış ve zararlı doğal denge sınırına indirilmiştir (Keskinalemdar vd. 1986; Aksu, 2011). Ancak ilk defa 1984 yılında tespit edilen Ips typographus, 2000'li yıllardan sonra toplu ağaç ölümlerine neden olmaya başlamıştır. Ips typographus'a karşı 2003 yılından itibaren yoğun bir şekilde biyoteknik ve mekanik mücadele çalışmaları yürütülmüştür (Çoşkun vd., 2010; Özkaya vd., 2010). Mücadelenin en yoğun yapıldığı 2003-2011 yıllarında, böceğin zarar yaptığı sahalara asılan feromon tuzakları ile yaklaşık 303617500 adet Ips typographus ergini toplanarak imha edilmiştir. Sarıyıldız vd., (2006) yılında Hatıla Vadisi Milli Park sahasındaki ladin meşcerelerinde Ips typographus zararı ile ilgili yapmış oldukları çalışmada, toprak ve meşcere özellikleri arasında negatif bir ilişki olduğu tespit edilmiş ve genel olarak, çok zarar gören meşcereler en düşük toprak organik maddesi ve besin elementlerine sahip olurken, bunu az zarar gören ve kontrol meşcereleri izlemiştir (Sarıyıldız vd., 2010). Başka bir çalışmada ise, Doğu Ladininin geliştiği alanlardaki doğal faktörler örneğin yetiştiği alandaki toprak ve meşcere özellikleri ve iklim şartları alandaki Doğu Ladini meşcerelerine Ips typographus kabuk böceğinin saldırısını önemli derecede etkilemektedir (Sarıyıldız vd., 2008), ayrıca kum miktarının yüksek, organik madde ve bitki besin elementlerinin az olduğu topraklar üzerinde gelişen Doğu Ladini meşcereleri Ips typographus zararlısının saldırılarına daha duyarlıdırlar (Sarıyıldız vd., 2008). Şavşat Orman İşletme Müdürlüğü, Şavşat İşletme Şefliğinde 2014 yılından itibaren, Efkar tepe mevkii ve Elmalı mevkiinde ladin ağaçlarında münferit olarak başlayan ağaç kurumaları, 2016 yılından itibaren artış göstererek, 2018-2019 yıllarında en üst seviyeye çıkmıştır. 100-110 nolu bölmelerde 2018 yilında 1159 adet, 2019 yılında 2342 adet olmak üzere toplam 3501 adet Ips typographus'un kuruttuğu ağaçlar kesilerek alandan çıkarılmıştır. D.micans ve I. typographus'un ardından Pristiphora abietina (Christ) 2008 yılında Şavşat'ta zarar yapan böcek türü olarak literatüre girmiştir (Aksu vd.,
2008). Gürcistan ladin ormanları üzerinden ülkemiz ormanlarına giriş yapan istilacı türlerden, D.micans'in ve I. typographus'un işgal ettiği ladin ormanlarımızın tamamında, yerli böcek türümüz olan $I$. sexdentatus'un zararı da mevcuttur (Özkaya vd., 2010).

Dünya genelinde ibreli ormanlardaki kabuk böceklerinin epidemi yapmasına neden olan faktörler arasında, iklim koşullarının olumsuzluğu ve ağaçlarda kar kırması, fırtına devriği, toprak kayması ve sel gibi olaylar sonucu köklerin açığa çıkması gibi olaylar sonucunda meşceredeki ağaçların zayıf düşmesi gelmektedir. Stres ağaçların dış etkenlere hassas hale gelmesinde önemli bir rol oynamaktadır. Stres faktörlerinin başında kuraklık, yani su açığı gelmektedir. Yapılan araştırmalarda, kuraklığın etkisiyle meydana gelen ağaç kurumalarının \%25'inde böcek zararı ve ağaç hastalıkların etken olduğu belirlenmiştir (Semerci vd., 2006; Şimşek vd., 2010a,b).

Ladin, sarıçam, göknar gibi iğne yapraklı ağaçların reçinesi kabuk böceklerinin girişine karşı kullandıkları en önemli direnç faktörüdür. Ağaçların kabuğunu delerek veya lokal yaralardan içeriye girmeye çalışan böcekler ağaçları ürettikleri reçine tarafindan engellenmektedir. Sağlıklı ağaçların kabukları altında kristalleşmiş reçine içerisinde ölü halde kabuk böceklerinin görülmesi; bu ağaçlardaki reçinenin kabuk böceklerine karşı bir tuzak gibi işlev görmesinden dolayıdır (Şimşek vd., 2010).

Kuraklık, su ve toprak yapısı sonucu besin stresi, ibreli ağaçların fizyolojisi ve fenolojisini etkileyerek savunma mekanizması olan reçine üretimini de olumsuz yönde değiştirecektir Toprakta bulunan kullanılabilir su durumu ve toprak özellikleri ile zararlı böceklere karşı ağaçların göstereceği pozitif direnç arasında doğrusal bir ilişki bulunmaktadır (Şimşek vd., 2006).

Kabuk böceği salgınının olduğu ormanlık alanlarda iklim kadar toprak özelliklerinin de ele alınması gerekmektedir. Bu amaçla, kurumaların yoğun olduğu Artvin Orman Bölge Müdürlüğü, Şavşat Orman İşletme Müdürlüğü, Şavşat Orman İşletme Şefliği Ladin (Picea orientalis) ormanlarında, 100-110 nolu bölmelerde, Ips typographus'un epidemi yapmasinda ana sebebinin bazı toprak özellikleri ile ilgili olup olmadığının araştırılması amacıyla bu çalışma, 2019-2020 yılları arasında yürütülmüştür.

\section{MATERYAL VE METOT}

Artvin Orman Bölge Müdürlüğü, Şavşat Orman İşletme Müdürlüğü'ne bağlı Şavşat Orman İşletme Şefliğinde yayılış gösteren, Picea orientalis'lerin kuruyan sahalar ile sağlıklı ağaçların bulunduğu alanlarda çalışma yapılmıştır. Alanlardaki toprak örnekleri, Ips 
typographus'a özgü feromon tuzakları ve dispenserleri çalışmanın ana materyalini oluşturmuştur. Çalışmada, GPS, stereo mikroskop, plastik kaplar ve naylon poşet diğer materyal olarak yer almıştır.

Çalışma alanının koordinatları; I. typographus'un bulunmadığı Veliköy Orman İşletme Şefliği 179 nolu bölmenin koordinatlar1, Y-283602, X-4573528 ve $I$. typographus'un zarar yaptığı, Şavşat Orman İşletme Şefliği 110 nolu bölmenin koordinatları ise Y-278242, X4571130 olarak tespit edildi. Zarar gören çalışma sahasının meşcere tipi; Lc3-1, Lc3-2, Çsbc-2 ve Mab3. Meşceredeki ağaçlar II (20-40 yaşında), III (40-60 yaşında) ve IV (6080 yaşında) yaş sınıfında, İşletme Amacı Toprak koruma J (Ladin + Sarıçam İşletme Sınıfı), İşletme Amacı Doğayı Koruma (Meşe + Ladin + Sarıçam İşletme Sınıfi), D (Meşe İşletme Sınıfi) işletme sınıfında, işletmenin amacı toprağı ve doğayı korumaktır. Meşcere iki kapalı orta ve ince ağaçlardan oluşan ladin, sarıçam ve meşe genç meşcereleri olup 52,4 hektardır. Meşcerede böcek salgını nedeniyle ölen ağaçlar çıkarılmaktadır.

Çalışma alanının bulunduğu Şavşat ve Veliköy Orman İşletme Şeflikleri, Doğu Karadeniz Bölgesi içinde kalır ve işletmenin topoğrafik yapısı genel olarak dağlıktır. Dağlar doğu batı istikametinde uzanır. Şeflikler Şavşat İlçesine 0-20 km mesafededir. Coğrafi olarak işletme şeflikleri Karadeniz Bölgesinde, Artvin İli sınırları içerisinde kalmaktadır. Şavşat'tan Artvin Şehir merkezine uzaklığı 68 km dir. En yakın İl merkezi Ardahan olup 53 km dir. Şefliklerin jeolojik ve mineorolojik yapısı, kuzeyi üçüncü zamana ait olup anakaya andezit, spilit, porfirit, bazalt ve doleritten oluşmaktadır. Güneyi ise ikinci zamanın devresine ait olup volkaniktir (Anonim, 3).

2019 yılı ve 2020 yılının Ocak ayında, 100 ve110 nolu bölmedeki kuru ve yarı kuru ağaçlar incelenmiş, böceklerin odunda biraktığı ana yollara göre zararlı böceklerin tür tespitleri de yapılmıştır. Ips typographus'un zarar yaptığı bu iki bölmedeki ağaçların \%10'u yarı kuru böcekli ve \%30'u tamamen kuru olmak üzere, bölmelerin \%40’nı böcekli ağaçlar oluşturmaktadır. Ayrıca yarı kuru ağaçların kabuk altlarından alınan ergin kabuk böcekleri, plastik kaplarla Artvin Bölge Müdürlüğüne bağl1, biyolojik mücadele laboratuvarına getirilerek, mikroskop altında incelenerek türlerin tespiti yapılmıştır.

Ladin ağaçlarının yoğun kuruma gösterdiği sahalar ile sağlıklı sahalardan tahlil için toprak örnekleri alınmıştır. Toprak örnekleri 1050 ile 1250 metre yükseklikten 10 adet sağlıklı ve 10 adet de 950 ile 1110 metre yükseklikteki kurumaların yoğun olduğu alanlardan toprak çukurları açılarak alınmıştır. 0-20 cm derinlikte, toplam 20 noktadan yaklaşık $40 \mathrm{~kg}$ toprak örneği alınarak, Artvin Çoruh Üniversitesi Orman Fakültesi toprak laboratuvarında, topraklardaki $\mathrm{pH}$ değeri, kum, kil, toz ve organik madde tahlilleri yapılmıştır. Toprakların tekstür tayini Bouyoucos'un hidrometre yöntemine göre yapılmıştır (Bouyoucus, 1951). Toprak örneklerinin organik madde miktarı 0,2 mm'lik elekten geçirilmiş $0,5 \mathrm{gr}$ lık örnekler üzerinden Walkley - Black' in islak yakma yöntemine göre yapılmıştır (Irmak, 1972; Gülçur, 1974). Toprak örneklerinin $\mathrm{pH}^{\prime}$ s1 1/2,5 oranında toprak-saf su karışımında Orion 420 A dijital pH metresi ile ölçülmüştür (Gülçur, 1974).

Çalışma alanına ait meteorolojik veriler (sıcaklık ve yağış) Artvin Meteoroloji İstasyonu'ndan alınmış olup, kurumaların olduğu, 2008-2009 y1lı ve 2018-2019 yıllarındaki iklim verileri de karşılaştırılmıştır. Karadeniz Bölgesinin nemli iklim ve Doğu Anadolunun karasal iklim arasındaki geçiş zonunda yer alan Şavşat, Doğu Karadeniz Bölgesinde hüküm süren iklim koşullarının genel özelliklerini göstermektedir. İklimin karakteristiği, kışların 1lık, yazların sıcak ve çok yüksek yağışların sıkça görülmesidir. İlçenin yıllık toplam yağış miktarı 698,7 mm, yağışın en yüksek olduğu ay Aralık (91,2 mm), en düşük olduğu ay ise Ağustos (29,4 mm) tur. İlçenin yıllık ortalama sıcaklığı $12,2^{\circ} \mathrm{C}$ dir. En yağışlı mevsim kış (445 $\mathrm{mm}$ ) iken en kurak mevsim ise yazdır (276 mm). Bölgenin yağış rejimi; yaz kuraklığı Akdeniz rejiminde olduğu kadar şiddetli olmamakta ve en yağışlı devre kış mevsimine rastlamaktadır. İlkbahar ve sonbahar yağışları arasındaki fark Akdeniz Bölgesi'ndekinden daha az olmakla birlikte Akdeniz ve Karadeniz rejimleri arasındaki geçiş tipi ifadesine uymaktadır. Her mevsimi yağışlı Karadeniz iklimi ile kara iklimi arasında bir geçiş bölgesi karakteri taşımaktadır (Anonim, 1).

\section{BULGULAR VE TARTIŞMA}

Kurumaların yoğun olduğu alanlarda tespit edilen Dendroctonus micans, Ips sexdentatus ve Ips typographus'un yoğun olarak bulunduğu görülmüştür. $\mathrm{Bu}$ türlerin yanı sıra, ülkemiz ladin ormanlarında son yıllarda tespit edilen Ips amitinus (Eichhoff), Ips cembrae (Heer) ve Ips duplicatus (Sahlberg) türlerinin de varlığ belirlenmiştir. $\mathrm{Bu}$ kabuk böcekleri birinci zararlı konumunda değildir, ancak Ips typographus ile birlikte bulunmakta ve Ips typographus'un ve diğer kabuk böceklerinin zayıf düşürdüğü ağaçlara giderek, ağaçların ölümüne katkı sağlamaktadırlar (Aksu vd., 2014).

Toplu ağaç ölümlerinin olduğu sahalarda, 9501110 metre yükseklikte bulunan 100 ve 110 nolu bölmeler için meteorolojik veriler incelendiğinde, 2008 yılında aylık ortalama minimum sicaklık $8,5^{\circ} \mathrm{C}, 2009$ yilında $8,9^{\circ} \mathrm{C}$ de iken, 2018 yilında $10,1^{\circ} \mathrm{C}, 2019$ yılında ise $10,0^{\circ} \mathrm{C}$ arasında ölçülmüştür. 2008 yılında aylık maksimum sicaklık $25,5^{\circ} \mathrm{C}, 2009$ yılında $24,9^{\circ} \mathrm{C}$ iken, 2018 yılında $28,0^{\circ} \mathrm{C}$, 2019 y1lında $26,9^{\circ} \mathrm{C}$ olarak ölçülmüştür. Bu verilere göre 2019 yılında sıcaklığın artış göstermesi sonucu, kabuk 
böceklerinin biyolojilerini etkileyerek generasyon sayısının artmasına neden olmuştur. 2008 yılında yıllık ortalama yağış miktarı $600,4 \mathrm{~mm}, 2009$ yılında $888,2 \mathrm{~mm}$ iken, 2018 yllinda $576,4 \mathrm{~mm}, 2019$ yılında ise $426,5 \mathrm{~mm}$ olduğu görülmektedir. Buna göre, çalışmanın yapıldığı alanda 2019 yılında yağış miktarının düştügü belirlenmiştir (Tablo 1).

Yağışlar sonucu topraktaki su durumu ile zararlı kabuk böceklerinin saldırılarına karşı ağaçların göstereceği direnç arasında doğrusal bir ilişki vardır (Nageleisen 2004a,b). Kurak ve sıcak hava dalgaları; ağaçların biyotik ve abiyotik nedenlerle zayıf düşürülmesinde en önemli paya sahiptir. Bazı Avrupa ülkelerindeki plantasyonlarda ağaç türlerinin seçiminin isabetsiz olduğu, 2003 yllında görülen kuraklık sırasında anlaşılmıştır (Belrose vd., 2004; Rouault vd., 2006).

Tablo 1. Artvin İli 2000-2019 Y1lları Arasındaki Meteorolojik Değerler.

Table 1. Meteorological Values Between 2000 and 2019 in Artvin Province.

\begin{tabular}{cccccc}
\hline Yillar & $\begin{array}{c}\text { Ortalama } \\
\text { Minimum } \\
\text { Sicaklık } \\
\left({ }^{0} \mathrm{C}\right)\end{array}$ & $\begin{array}{c}\text { Meteorolojik Değerler (Aylık Ortalama) } \\
\text { Ortalama } \\
\text { Maksimum } \\
\text { Sicaklık } \\
\left({ }^{0} \mathrm{C}\right)\end{array}$ & $\begin{array}{c}\text { Aylık } \\
\text { Ortalama } \\
\text { Sicaklık } \\
\left({ }^{0} \mathrm{C}\right)\end{array}$ & $\begin{array}{c}\text { Ortalama } \\
\text { Nispi } \\
\text { Nem }(\%)\end{array}$ & $\begin{array}{c}\text { Ortalama } \\
\text { Yağış } \\
(\mathrm{mm})\end{array}$ \\
\hline 2000 & 8,3 & 24,7 & 11,8 & 11,8 & 548,5 \\
2003 & 8,1 & 25,2 & 11,7 & 11,7 & 738,5 \\
2008 & 8,5 & 25,5 & 12,4 & 12,4 & 600,4 \\
2009 & 8,9 & 24,9 & 12,7 & 12,7 & 888,2 \\
2018 & 10,1 & 28,0 & 14,5 & 14,5 & 576,4 \\
2019 & 10.0 & 26,9 & 13,7 & 13,7 & 426,5 \\
\hline
\end{tabular}

Artvin ladin ormanlarında Ips typographus'un epidemi yaptığı 2003 yılı öncesi 2000 yılında yıllık ortalama yağış miktarı $548,5 \mathrm{~mm}$ olmuştur. 2000 yılı ile 2019 yılları arasındaki yağış değerleri karşılaştırıldığında, 2009 yılında yıllık ortalama yağış miktarının 888,2 mm olduğu ve bu yıllarda ladinlerin sağlığında 2003 yıla oranla bir problem görülmemiştir. Ancak 2019 yılında ortalama yağış miktarının, 2000 yılındaki değerlere yakın olduğu, 2009 yılına oranla $461,7 \mathrm{~mm}$ daha az yağış aldığı tespit edilmiştir. 2018 yılında mayıs ayında metre kareye 65,6 mm, Haziran ayında 42,3 mm, 2019 yılında Mayıs ayında $45,4 \mathrm{~mm}$, Haziran ayında $26,3 \mathrm{~mm}$ yağış alması nedeniyle, 2018-2019 yıllarında Artvin Şavşat ladin ormanlarının daha az yağıș aldığı ve 2018 yılı mayıs ayı aylık ortalama sıcaklığın $18,4^{\circ} \mathrm{C}$, Haziran ayında $21,1^{\circ} \mathrm{C}$ ve 2019 yılında Mayıs ayında ortalama aylık sicaklığın $18,1^{\circ} \mathrm{C}$, Haziran ayında ise $22,4^{\circ} \mathrm{C}$ sıcaklığa ulaştığ için, ladin ormanlarının bu olumsuz şartlardan etkilendiği düşünülebilir.

Feromon tuzaklarına yakalanan Ips typograhus yoğunluğu incelendiğinde; 1984 yllından itibaren en ciddi epidemisini 2003 yılında yapmıştır. I. typographus 19982007 yılları arasında 617268 metre küp ladin ağacını kurutmuştur. I. typographus'a karşı yürütülen biyoteknik mücadele çalışmalarında, 2003-2011 yılları arasında zararlının en yoğun olduğu 65769 hektarlık alana 102902 adet feromon tuzağ I.typographus ergini tuzaklara çekilerek imha edilmiştir. 2003 y1lında ortalama bir tuzağa 4642 adet ergin düşerken, 2012 yilında bir tuzağa 1087 adet ergin böcek düşmüștür. 2018 ve 2019 y1llarında toplam 6060 adet feromon tuzağ 1 asılarak, yaklaşık 19594500 adet ergin I. typographus ergini toplanmıştır. 2018 y1lında Şavşat Orman İşletme Müdürlüğü ladin ormanlarına 600 adet feromon tuzağ 1 asılarak, toplam 2856413 adet, 2019 yilında toplam 750 adet feromon tuzağı asılarak toplam 2730000 adet $I$. typographus ergini tuzaklara çekilerek imha edilmiştir. Şavşat İşletme Müdürlügünde 2018 yılında bir tuzağa ortalama 4761, 2019 yılında ise 3640 adet ergin böcek düşmüştür (Anonim 2). 2018 yllında bir tuzağa düşen $I$. typographus adedinin, 2003 yılındaki tuzak ortalamasının üstüne çıktığı, 2019 yılındaki tuzak ortalamasının ise 2003 yılındaki tuzak ortalamasına yaklaştı̆ı tespit edilmiştir. $I$. typographus bu çalışmalar sonucunda 2012 yilında doğal denge sınırına çekilmişken, 2018 ve 2019 yıllarındaki yukarı doğru hareketliliğin, doğal olayların bir sonucu olarak, kuraklık ve buna bağlı, topraktaki bazı maddelerin alımının azalması belirleyici bir sebep olarak düşünülebilir.

Orman ağaçlarında görülen olumlu ve olumsuzlukların asıl nedenleri arasında toprağın fiziksel ve kimyasal özellikleri öne çıkmaktadır. Doğu Karadeniz ladin sahalarında genel olarak kumlu ve balçıklı topraklar görülmektedir. Doğu ladininin bu tip hafif toprakları daha fazla tercih ettiğini söylemek mümkündür (Akgül, 1975). Çalışmanın yürütüldüğü orman alanlarında, toprak profilleri alınarak yapılmış olan fiziksel ve kimyasal analiz sonuçları Tablo 2 ve 3'de verilmiştir.

Tablo 2. Sağlıklı sahadan alınan toprak numunelerinin analiz değerleri.

Table 2. Some soil properties in healthy stands.

\begin{tabular}{|c|c|c|c|c|c|c|c|}
\hline Deneme No & Yükselti & $\mathrm{pH}$ & Org. Mad. & Kum \% & Kil \% & Toz\% & Toprak Türü \\
\hline 1 & 1050 & 5,89 & 5,96 & 70,32 & 29,12 & 0,57 & Kumlu Kil \\
\hline 2 & 1050 & 6,14 & 6,37 & 57,04 & 30,37 & 12,59 & Kumlu Kil \\
\hline 3 & 1050 & 6,2 & 6,68 & 60,66 & 32,72 & 6,62 & Kumlu Kil \\
\hline 4 & 1150 & 6,08 & 6,01 & 58,19 & 22,66 & 19,15 & K. Killi Balçık \\
\hline 5 & 1150 & 6,69 & 6,43 & 53,87 & 27,1 & 19,03 & Hafif Kil \\
\hline 6 & 1250 & 6,04 & 4,43 & 56,75 & 20,25 & 23 & Killi Balçık \\
\hline 7 & 1250 & 6,65 & 4,67 & 71,91 & 13,02 & 15,08 & Kumlu Balçık \\
\hline 8 & 1250 & 5,99 & 6,72 & 67,8 & 13,93 & 18,28 & Kumlu Balçık \\
\hline 9 & 1250 & 5,51 & 4,66 & 71,82 & 13,88 & 14,3 & Kumlu Balçık \\
\hline 10 & 1250 & 5,73 & 2,91 & 76,03 & 17,8 & 6,18 & K. Killi Balçık \\
\hline Ortalama & & 6,09 & 5,48 & 64,44 & 22,08 & 13,48 & \\
\hline
\end{tabular}

Tablo 3. Yoğun kurumaların olduğu sahadan alınan toprak numunelerinin analiz değerleri.

Table 3. Some soil properties in bark beetle infected stands.

\begin{tabular}{|c|c|c|c|c|c|c|c|}
\hline Deneme No & Yükselti & $\mathrm{pH}$ & Org. Mad. & Kum \% & Kil \% & Toz \% & Toprak Türü \\
\hline 1 & 1110 & 6,13 & 6,48 & 64,7 & 14,98 & 20,31 & Balçık \\
\hline 2 & 1100 & 6,83 & 6,43 & 60,92 & 20,12 & 18,95 & K. Killi Balçık \\
\hline 3 & 1110 & 5,72 & 6,45 & 50,62 & 27,52 & 21,86 & Hafif Kil \\
\hline 4 & 1100 & 5,92 & 5,1 & 46,16 & 28,82 & 25,02 & Hafif Kil \\
\hline 5 & 1110 & 6,03 & 6,8 & 57,24 & 22,63 & 20,12 & Killi Balçık \\
\hline 6 & 975 & 5,47 & 5,2 & 29,82 & 48,05 & 22,13 & Ağır Kil \\
\hline 7 & 975 & 6,63 & 5,97 & 43,21 & 38,2 & 18,59 & Hafif Kil \\
\hline 8 & 950 & 5,61 & 2,59 & 53,02 & 26,78 & 20,2 & Hafif Kil \\
\hline 9 & 950 & 5,81 & 5,61 & 54,87 & 35,37 & 9,76 & Hafif Kil \\
\hline 10 & 975 & 5,97 & 5,14 & 54,59 & 26,89 & 18,52 & Hafif Kil \\
\hline Ortalama & 1110 & 6,01 & 5,58 & 51,52 & 28,94 & 19,55 & \\
\hline
\end{tabular}


Yapılan tahliller sonucunda, sağlıklı sahalardan alınan topraklarda organik madde miktarın ortalama $\% 5,48, \mathrm{pH}$ değeri 6,09 , kum değeri $\% 64,44$, kil değeri $\% 22,08$ ve toz değeri \%13,48 dir. Kurumaların yoğun olduğu sahalardan alınan topraklarda ise organik madde miktarı ortalama \%5,58, pH değeri 6,01, kum değeri $\% 51,52$, kil değeri $\% 28,94$ ve toz değeri $\% 19,55$ olarak tespit edilmişsir.

Tahlil sonuçlarına göre, ladin ağaçlarının sağlıklı olduğu yerlerdeki topraklarda ortalama kum değeri \%64,44 iken, hastalıklı olan alanlardaki ortalama kum değeri ise \%51,52 olmuştur. Hastalıklı olan sahalarda kum oranının sağlıklı sahalara oranla düşük olması, kum bakımından zengin olan toprakların daha iyi havalanması ve ağaçların toprağın daha derin katmanlarına köklerini geliştirmelerine imkan vermektedir. Bu durum, ağaçların kurak devrede derin toprak katmanlarından su alarak stresten daha az etkilendikleri ihtimalini güçlendirmektedir. Topraklardaki kil miktarı sağlıklı ladin ağaçlarının görüldüğü alanlarda ortalama \%22,08 iken, hastalıklı bireylerin olduğu alanlarda bu değer ortalama \%28,94 olmuştur. Kurumaların yoğun olduğu sahalarda kil miktarının, sağlıklı ladin ağaçlarının bulunduğu sahalara oranla artış göstermesi, muhtemelen toprakta kötü havalanma koşulları oluşturmuş ve köklerin derin toprak katmanlarına ulaşmasını engellemiştir. Derin toprak kısmından su alamayan ladin ağaçlarının da daha fazla strese girmiş olabileceği sanılmaktadır. Toprak türünün genellikle kumlu kil ve balçık olduğu, toprak pH'sının genellikle hafif asit, nadiren orta derece asit veya nötr olduğu, kireç kapsamı bakımından az kireçli olarak sınıflandırıldığı, organik madde bakımından ise toprağın üst katmanlarının $(0-20 \mathrm{~cm})$ orta derece organik madde içeriğine sahip tuzsuz topraklar olduğu anlaşılmaktadır.

Çalışma sahasından alınan toprak numunelerin ( 0 $20 \mathrm{~cm}$ ) fiziksel ve kimyasal özelliklerinin belirlenmesi sonucunda, sağlıklı ve kurumaların yoğun olduğu sahalarda kumlu killi balçık, kumlu killi, hafif killi, killi balçık, balçık, ağır killi ve kumlu balçık türündeki araştırma sahaları toprakları nötr ve hafif asitli reaksiyona sahiptir. Ortalama kum, toz ve kil oranları bakımından sağlıklı sahalarda sırasiyla, $\% 64,44, \% 13,48$ ve $\% 22,08$. Kurumaların yoğun olduğu sahalarda, $\% 51,52, \% 19,55$ ve $\% 28,94$ dur. Toprak reaksiyonu ortalama $(\mathrm{pH})$ değerleri 6,01-6,09 arasında olması hafif asitli sınıfında olduğu, bu $\mathrm{pH}$ derecelerinde bitki besin elementlerinin, bitkiler tarafindan alımında herhangi bir sorun bulunmamaktadır. Toprağın organik madde bakımından $(\% 5,48$ ve $\% 5,58)$ yüksek olduğu görülmektedir. Toprak türünün genellikle sağlıklı sahalarda kumlu kil ve kumlu balçık, kurumaların yoğun olduğu sahalarda ise hafif killi olduğu, toprak pH'ının genellikle her iki deneme sahasında da hafif asitli olduğu, nadiren nötr olduğu, organik madde bakımından zengin olduğu anlaşılmıştır.

$\mathrm{Bu}$ konuda yapılan araştırmalarda, ince tekstürlü toprakların üst tabakalarında daha çok su tutulur ve buharlaşmaya maruz kalan üst toprak tabakalarından daha fazla su kaybı olabilmektedir. Ağaçların topraktan alabileceği su miktarının azalması, ağaç gelişimini olumsuz etkileyen bir faktördür. Kuraklık ve su stresinin böcek salgınlarıyla ilişkisi konusunda yapılmış bazı araştırmalar da bu duruma işaret etmektedir (Christiansen ve Bakke 1997; Hanks vd.,1999; Williams ve Liebhold, 2002; Bentz vd., 2010; Öner vd., 2010; Şimşek vd., 2010a; Sarıkaya ve Yıldırım, 2011; Laz vd., 2018).

Özellikle kabuk böceği zararı görülen alanlardaki üst toprağın besin maddeleri bakımından zengin nitelikte olması, ağaçların gelişimi açısından olumlu bir durum olmaktadır. Oysa fakir topraklardaki ağaçlar, ihtiyaç duyduğu madde alımı yeterli olmadığından kabuk böceklerine karşı daha hassas duruma gelecektir. Ips typographus'un epidemi oluşturduğu alandaki toprak yapısının ve su durumunun bu salgında rolü olduğu düşünülmektedir. Strese bağlı olarak orman ağaçlarının kabuk böceği saldırılarına karşı daha hassas olduğu da ifade edilmektedir (Akkuzu ve Güzel, 2015). Dünyada yapılan bir çok çalışmada orman zararlısı kabuk böceklerinin oluşturduğu salgının kuraklık ve orman toprak özellikleriyle ilişkili olduğu belirtilmektedir (Dobbertin vd., 2007; Vilhar, 2016).

Kuraklığa maruz kalan ağaçlarda zararlı böceklerden etkilenme, hastalıklara yakalanma durumları daha fazla görülebilmektedir. Sağlıklı ladin, çam ve göknar ağaçlarının kabuk böceklerine karşı kullandıkları en önemli savunma silahı salgıladıkları reçinelerle kabuk böceklerinin girişini engellemeleridir (Göktürk ve Aksu, 2011). Ağaçların reçine üretimlerini su tüketerek yaptıkları dikkate alındığında kuraklık durumunda ağacın yeteri miktarda reçine üretemediği görülmekte bu da bu tür ağaçların böcek ve hastalıklara daha hassas duruma gelmesine neden olmaktadır.

Ladin bireylerinin sağllklı olduğu yerlerdeki topraklarda ortalama $\mathrm{pH}$ değerleri 6,09 iken, ağaç kurumalarının yoğun olduğu alanlarda ortalama $\mathrm{pH}$ değeri ise 6,01 olmuştur. Yoğun kurumaların olduğu sahalarda ve sağlıklı sahalardaki $\mathrm{pH}$ değerleri arasında fazla bir fark yoktur. Ladin, $\mathrm{pH}$ değeri 5,5 ve 6,5 değerleri arasındaki orta asitli topraklarda daha iyi gelişme gösterirler (Akgül, 1975). Ladin bireylerinin sağlıklı olduğu yerlerdeki topraklarda ortalama organik madde değeri \%5,48 iken, hastalıklı olan alanlardaki ortalama organik madde değeri $\% 5,58$ olmuştur. Bu noktada da organik madde miktarının artması toprakların su tutma kapasitesini ve nemliliğini artırması gerekirken yağışların istenilen düzeyde 
olmadığından ladinlerin su ihtiyacını karşılayamadığ düşünülmektedir (Tablo 2, 3).

\section{SONUÇ VE ÖNERILER}

Çalışma alanında, önceki yıllarda yoğun olarak $D$. micans ve $I$. typographus'un zararına uğramış ve uygulanan mücadele yöntemleri ile doğal denge sınırına indirilmiştir. Doğal olaylardan kaynaklanan sorunlar (kuraklık, sıcaklı ve topraktaki değerlerin değişmesi vb.) kabuk böceğinin yeniden popülasyon artı̧̧ yapmasına neden olmuştur.

Ağaç ölümlerinin yoğun olduğu sahalarda, balçıklı toprak oranının az olması nedeniyle, bu tipteki toprakları ladinlerin fazla tercih etmediği, ayrıca hafif killi topraklarda da ağaç ölümlerinin çoğaldığı, buna karşılık kum oranının fazla olduğu toprak türü, kumlu kil, kumlu balçıklı topraklardaki ağaçların sağlıklı olduğu görülmüştür.

Sahalardan alınan toprak tahlilleri sonucunda, ladin ağaçlarının sağliklı olduğu yerlerdeki topraklarda ortalama kum değeri \%64,44, hastalıklı olan toprakta kum değeri ise $\% 51,52$ olarak tespit edilmiştir. Kurumaların yoğun olduğu sahalarda, kurumaların az olduğu sahalara kıyasla, kum oranı nispeten düşük, kil oranın ise yüksektir. İyi havalanan kumlu topraklarda ağaçlar köklerini daha derin toprak katmanlarına gönderebilmekte ve kurak devrelerde derindeki suyu kullanabilmektedir. A Ağı bünyeli killi topraklarda havalanma sorunu yüzünden ağaçlar derin toprak katmanlarına çoğu zaman kök geliştirememektedir. Bu durum onları kuraklık stresine karşı daha hassas hale getirmektedir. Kurak mevsimlerde toprak yapısını da dikkate alarak, kabuk böcekleriyle, özellikle dünyanın en tehlikeli kabuk böceği olarak kabul edilen I. typographus ile mutlaka mücadele edilmelidir. Özellikle yağıșın az olduğu kurak mevsimlerde mücadele yöntemlerinin tümünün eksiksiz ve zamanında yapılmasına özen gösterilmesi gerekmektedir.

\section{TEŞEKKÜR}

Makalede tespit edilen böceklerin teşhisi ve feromon tuzaklarının değerlendirilmesinde vermiş olduğu destekten dolayı Biyolog Yaşar Aksu'ya teşekkür ederim.

\section{KAYNAKLAR}

Akgül, E. (1975). Türkiye'de Doğu Ladininin (Picea orientalis Link ve Carr.) yayılış sahası, topraklarında tespit edilen başlıca özelliklerle bunlar arasında ilişkiler. Ormancılık Araştırma Enstitüsü Teknik Bülteni, Seri No: 71. Ankara.
Akkuzu, E. \& Güzel, H. (2015). Edge effects of Pinus nigra forests on abundance and body length of Ips sexdentatus. Izvorni znanstveni članci, 9(10), 447-453.

Aksu, Y. \& Göktürk, Ç.B. (2008). Picea orientalis ormanlarında zarar yapan Pristiphora abietina (Christ) (Hymenoptera: Tenthredınıdae)'nin biyolojisi, morfolojisi ve mücadelesi üzerine yapılan araştırma. Orman Mühendisleri Dergisi, 45(11), 35-39.

Aksu, Y. (2011). Rhizophagus grandis Gyll.(Coleoptera: Rhizophagidae)'nin biyolojisi, laboratuvar şartlarında üretim yöntemleri, ormanlara verilmesi, yapılan mücadele ve alınan sonuçlar. Süleyman Demirel Üniversitesi Orman Fakültesi, Türkiye 1. Orman Entomolojisi ve Patolojisi Sempozyumu, Kasım 2011, Antalya. Bildiriler Kitabl, 73-79.

Aksu, Y., Dedeağaoğlu, C. \& Göktürk, Ç.B. (2014). Doğu Karadeniz ladin (Picea orientalis) ormanlarının eski ve yeni zararlı kabuk ve yaprak böcekleri. Orman ve Av Dergisi, 5, 24-27.

Anonim. 1. Orman Genel Müdürlüğü arşivleri. www.ogm.gov.tr. Erişim tarihi; 03.04.2020

Anonim. 2. Artvin Orman Bölge Müdürlüğü Koruma Şube Müdürlüğü arşiv verileri (Basılmamış)

Anonim. 3. Artvin Orman Bölge Müdürlüğü, Şavşat Orman İșletme Müdürlüğ̈̈ Ekosistem Tabanlı Fonksiyonel Orman Amenajman Planı 20132023. Ankara 2013. (Basılmamış)

Bentz, B.J., Régniére, J., Fettig, C.J., Matthew Hanse, E., Hayes, J.L., Hicke, J.A., Kelsey, R.G., Negron, J.F. \& Seybold, S.J. (2010). Climate change and bark beetles of the Western United States and Canada: Direct and indirect effects. BioScience, 60, 602-613.

Bouyoucus, G.Y. (1951). A calibaration of the hydrometer for making mechanical analysis of soils. Agronomy Journal, 43(5), 434-438.

Christiansen, E. \& Bakke, A., (1997). Integrating cultural tactics into the management of bark beetle and reforestation pests. In: Grégoire, J.C., Liebhold, A.M., Stephen, F.M., Day, K.R., Salom, S.M. (Eds.), General Technical Report. USDA Forest Service, 163-171pp.

Coşkun, K.A., Aksu, Y. \& Göktürk, Ç.B. (2010). Picea orientalis ormanlarinda zarar yapan Ips typographus L, (Coleoptera: Scolytidea)'in biyolojisi, morfolojisi, yayılışı, zararl, yapılan mücadele çalışmaları ve alınan sonuçlar üzerine araştırmalar. Artvin Çoruh Üniversitesi Orman Fakültesi, III. Ulusal Karadeniz Ormancillk 
Kongresi, Mayıs 2010, Artvin, Bildiriler kitab1, IV. Cilt, Sayfa: 1309-1317,

Dobbertin, M., Wermelinger, B., Bigler, C., Bürg, M., Carron, M., Forster, B., Gimmi, U. \& Riglin, A. (2007) Linking increasing drought stress to Scots Pine mortality and bark beetle infestations. The Scientific Word Journal, 7, 231-239.

Keskinalemdar, E., Aksu,Y. \& Alkan, Ş. (1986). Rhizophagus grandis (Gyll)'in laboratuvar şartlarında üretimi ve biyolojik mücadele uygulamalarında kullanılması olanakları üzerine araştırmalar. Türkiye 1. Biyolojik Mücadele Kongresi. Şubat 1986, Adana, Bildiriler kitabı, 195-205.

Keskinalemdar, E., Alkan, Ş. \& Aksu,Y. (1987). Artvin ilinde Ips typographus L. (Coleoptera: Scolytidae)'in biyolojisi ve mücadelesi üzerine çalışmalar. Türkiye 1. Entomolojisi Kogresi, İzmir, 1987, Bildiriler kitab1, 737-742.

Gokturk, T. \& Aksu, Y. (2011). Use of pheromone traps against Tomicus piniperda and Tomicus minor in the Kazbegi National Park, Georgian Republic. African Journal of Agricultural Research, 6(10), 2430-2435.

Gokturk, T., Kordali, S., Çalmasur, O. \& Tozlu G (2011) Insecticidal effects of essential plant oils against larvae of Great Spruce Bark Beetle, Dendroctonus micans (Kugelann) (Coleoptera: Curculionidae: Scolytinae). Fresenius Environmental Bulletin, 20(9), 2365-2370.

Göktürk, T. (2009). Artvin ilinde orman ağaçlarında yaşayan Coleoptera (Insecta) türleri., Ecological Life Sciences, 4(3) 121-133.

Gülçur, F. (1974). Topră̆ın fiziksel ve kimyasal analiz metodları. İ.Ü. Orman Fakültesi Yayınları, No: 201, İstanbul.

Hanks, L.M., Paine, T.D., Millar, J.G., Campbell, C.D. \& Schuch, U.K. (1999). Water relations of host trees and resistance to the phloem-boring beetle Phoracantha semipunctata F. (Coleoptera: Cerambycidae). Oecologia, 119, 400-407.

https://artvinobm.gov.tr/site.

Irmak, A, (1972). Toprak ilmi. İÜ Orman FakültesiYayınları, No. 184, İstanbul.

Laz, B., Babür, E., Akpınar, D.M. \& Avgın, S.S. (2018). Kahramanmaraş-Elmalar yeşil kuşak ek-3 plantasyon sahasında görülen biyotik ve abiyotik zararlıların tespiti. KSÜ Tarım ve Doğa Dergisi, 21(6) 926-935.

Nageleisen, L.M. (2004a). Les insectes sous-corticaux des résineux en 2002: diminution inattendue des dommages dus aux scolytes. Min.Agri. Alim. Pêche Aff. Rur. (DGFAR), Paris.
Nageleisen, L.M. (2004b). Recrudescence des insectes sous-corticaux à la suite des extrêmes climatiques de 2003, in: Bilan de lasanté des forêts en 2003, Min. Agri. Alim. Pêche Aff. Rur., Paris.

Öner, N., Şimşek, Z., Kondur, Y., İmal, B. \& Şimşek, M. (2010). Küresel iklim değişikliği dikkate alınarak kurak ve yarıurak alanların ăgaçlandırılması ve zararlı böceklerle mücadelesine yönelik öneriler (Çankırı ili örneği). In, III. Ulusal Karadeniz Ormancılık Kongresi, Artvin, Bildiriler kitabl, 827-838.

Özkaya, M.S., Aksu, Y. \& Göktürk, Ç.B. (2010) Picea orientalis ve Pinus sylvestris ormanlarinda zarar yapan Ips sexdentatus (Boerner), (Coleoptera: Scolytidea)'in biyolojisi, morfolojisi, yayılışı, zararı, yapılan mücadele çalışmaları ve alınan sonuçlar üzerine araştırmalar. Artvin Çoruh Üniversitesi Orman Fakültesi, III. Ulusal Karadeniz Ormanc1lık Kongresi, May1s 2010, Bildiriler kitabl, IV. Cilt, 1318-1326.

Özkaya, M.S., Aksu, Y. \& Tuylu, N. (2010). Picea orientalis ormanlarinda Ips typographus'un mücadelesi için kullanılan feromon tuzaklarına düşen predatör böcek türlerinin tespiti üzerine araştırmalar. III. Ulusal Karadeniz Ormancılık Kongresi, Mayıs 2010, Bildiriler kitabl, IV. Cilt, 1301-1308.

Sarıkaya, O. \& Yıldırım, S. (2011). Isparta-Aksu Yöresi İğne Yapraklı Ormanlarının Scolytinae (Coleoptera: Curculionidae) Türleri. Bartın Orman Fakültesi Dergisi, 13, 38-50.

Sarıyıldız, T., Akkuzu E., Küçük M., Duman A. \& Aksu Y. (2008). Effects of Ips typographus (L.) damage on litter quality and decomposition rates of Oriental Spruce (Picea Orientalis (L.) Link.) in Hatila Valley National Park, Turkey, European Journal of Forest Research, 127(5), 429-440 (2008).

Sarıyıldız, T., Akkuzu, E., Tüfekçioğlu, A., Tilki, F., Güner, S., Aksu, Y., Küçük, M. \& Duman, A. (2010). Doğu Ladini ormanlarının Ips typographus saldirısina maruz kalmasinda yetişme ortamı ve meşcere özelliklerinin etkisi. III. Ulusal Karadeniz Ormancilık Kongresi, Mayıs 2010 Artvin, Bildiriler kitabı, Cilt IV, 1291-1300.

Semerci, A., Çelik, O., Şanlı, B., Şahin, Ö., Eczacıbaşı, B. \& Argun, N. (2006). İ̧ Anadolu Bölgesinde son beş yılda incelenen bazı ă̆aç kurumalarının nedenlerinin incelenmesi ve çözüm önerileri. Türkiye'de yarıkurak bölgelerde yapılan ağaçlandırma ve erozyon kontrolü uygulamalarının değerlendirilmesi çalıştayı, 7-10 Kasım 2006, Ürgüp, Nevşehir, 52-53s. 
Şimşek, Z., Kondur, Y. \& Şimşek, M. (2006). Küresel iklim değişikliğinin zararlı böcekler üzerine olası etkileri. In, IV. Çankırı kültürü bilgi şöleni, Çankırı, pp. 87-125.

Şimşek, Z., Kondur, Y. \& Şimşek, M. (2010a). Küresel iklim değişikliğinin kabuk böcekleri üzerinde beklenen etkileri. Biyoloji Bilimleri Araştırma Dergisi, 3, 149-157.

Şimşek, Z., Öner, N., Kondur, Y. \& Şimşek, M. (2010b). Kuraklığın orman biyoçeşitliliği üzerine etkileri ve gelecekte alınması gereken önlemler. Çölleşme ile mücadele sempozyumu, Çorum, Türkiye, 514521.

Vilhar, U. (2016). Comparison of drought stress indices in beech forests: a modelling study. Forest Biogeosciences and Forestry, 9, 635-642.

Williams, D.W. \& Liebhold, A.M. (2002). Climate change and the outbreak ranges of two North American bark beetles. Agricultural and Forest Entomology, 4, 87-99

Yüksek, T. (2017). Rize İli Arazi Kullanım Durumu, Bazı Ormancılık Çalışmaları ve Yağışların Zamansal Dağılımının Genel Bir Değerlendirilmesi. Anadolu Çev. ve Hay. Dergisi, 2(3), 59-66. 